\title{
Macro Events and Micro Responses: Experiences from Bolivia and Guatemala
}

\author{
Gabriela Alcaraz V.
}

\begin{abstract}
For Bolivia and Guatemala, the 2007-08 food price crisis contributed to a slowdown in the economy and increased unemployment. For the poorer population the crisis meant an overstretching of the household finances and increased difficulties for ensuring household food security. Since 2010, food price increases have continued in both countries. Bolivian and Guatemalan households have coped and adapted to their current economic stress through a diverse set of mechanisms affecting not only family structures, dynamics and productivity, but also their future economic prospects. At an aggregate level, the outcomes are substantial. The reported and measured changes in dietary quality and intake have certainly had an impact on the population's nutritional status and general health. Longer-term effects at the national level will likely follow in the coming years. In both countries, the national governments need to strengthen their efforts for facilitating the access to quality employment, social protection, and to affordable and nutritious foods.
\end{abstract}

\section{Introduction}

In 2014 the Life in a Time of Food Price Volatility project incorporated quantitative analyses that fed from and into the qualitative research component ${ }^{1}$ to contest and triangulate findings with nationally representative data and to complement the information that only each of the approaches can provide towards a more complete and wider picture. This article shows how macroeconomic events create impacts on micro-level economic and social realities, which in turn aggregate to macro-level social outcomes for the cases of Guatemala ${ }^{2}$ and the Plurinational State of Bolivia. ${ }^{3}$

The quantitative component of the research in Bolivia used nationally representative household data and other general economic and social information available from the literature and from official data sources for the years before and after the 2007-08 food price crisis. More specifically, the comparative analyses were based on the Latinobarómetro Surveys 2006-10 and the 2006 and 2011 Living Conditions Household Surveys (INE 2006a; INE 2011a). For Guatemala, the quantitative research component relied on nationally representative surveys and on general information about the country stemming from a variety of sources. The datasets used for the analyses were the
Latinobarómetro Surveys 2006-10 and the 2006 and 2011 Living Conditions Household Surveys ENCOVI (INE 2006b; INE 2011b).

\section{Macro-level cycles of crisis and recovery} The 2007-08 food, fuel and financial crises had varying effects across Latin America. Overall, by 2009 the regional gross domestic product (GDP) shrank by 1.9 per cent and unemployment rose 0.5 percentage points with respect to 2008. Further, declines were observed in private consumption and investment as well as in industrial production and commerce (ECLAC 2010). Countries that were net food, fuel, metal and mineral importers had the greatest difficulties in coping with the high commodity prices.

In general terms, the recovery from the crisis was fast. By 2010 many national economies had growth rates similar to those observed before the crisis and stabilisation was achieved. In 2011 and 2012 the regional economic growth rate slowed again, due to uncertainty in the international economic environment that affected external trade and variability in domestic investment. Continuous increases and volatility in the prices of certain food products have impacted inflation since 2010 (CEPAL 2012). Price volatility affects consumption, which for 
Latin America and the Caribbean also contributes to poverty, since the reduction in consumption leaves those households with incomes originally close to the poverty line, below it (ECLAC 2010).

For the cases of Bolivia and Guatemala, the situation was similar to the regional pattern, but with certain key distinctions. In Bolivia, after an economic contraction in 2009, the pre-crisis pace of economic growth (between 4 and 6 per cent annually) was regained after 2010. The main drivers for this performance were positive performance in the extractive industries (oil, natural gas, mining) and dynamism in investment, consumption and production (ECLAC 2013; Fundación Milenio 2014). As well, prudent monetary and fiscal macroeconomic policies, implemented since the early 2000s, increased Bolivia's resilience to shocks. Poverty has shown a sustained reduction going from 59.9 per cent in 2006 to 44.9 per cent in $2011 .{ }^{4}$ In this context, Bolivia was among the few countries in Latin America and the Caribbean having positive growth during the 2007-08 crisis (IMF 2014). Nonetheless, while minimum wages have risen annually and unemployment has been lower than in pre-crisis years, low-quality employment and poverty are still widespread. Bolivia remains one of the countries with the higher poverty rates in the region.

For the case of Guatemala, economic growth dropped considerably between 2007 and 2009 from 6.3 to 0.5 per cent (World Bank 2014). The occurrence of a series of natural disasters between 2009 and 2013 (hurricanes, storms, tropical depressions and severe droughts) and other climaterelated issues (i.e. coffee rust) further affected the country's economy. ${ }^{5}$ Similar to other Central American countries, Guatemala faced the reduction of export revenues, foreign direct investment, remittances from abroad and tourism. For the poorer segments of the population, contraction of the economy meant unemployment, increased informality in labour conditions and reduced household income and purchasing power. The resulting loss in national wealth created a challenge for the state in providing basic services and safety nets, even as there was an increase in poverty and inequality (KAS and laRED 2010; ECLAC 2010). Between 2006 and 2011 the prevalence of poverty increased from 51 to 53.7 per cent.

\section{Food price changes in Bolivia and Guatemala}

At the national level, the global food price crisis was further complicated by a combination of different factors. For instance, in Bolivia, the adverse effects of climatic events reduced food supply ${ }^{6}$ and led to increases in the price of fuel, agricultural inputs ${ }^{7}$ and wages. $^{.}$These in turn contributed to the increase in food prices. More recently, between 2010 and 2014 many communities were isolated by road blockades associated with political tensions, ${ }^{9}$ which interrupted food supplies and impacted on food prices. ${ }^{10}$

In Guatemala, by mid-2007 the trend in the increase in food prices started becoming evident. According to the World Food Programme, the wholesale price of maize, rice and beans ('basic grains') in the 2006-08 period increased substantially, registering cumulative variations ranging between 35.8 per cent (maize) and 101.4 per cent (rice) (PMA 2008). Seasonal price variations coupled with unfavourable climatic events and the country's strong reliance on food imports made the country very susceptible to food price increases over the period. Consumer prices presented even higher variation levels (ibid.). Basic grains being the primary components of the Guatemalan diet, particularly of the poor and of rural populations, the price increases had major implications on the amount of resources allocated for purchasing food.

In relation to the price changes for specific products, general sources document that sugar, rice, beef, noodles, certain vegetables, wheat flour, maize, potatoes and oil are the products that have registered constant price increments in both countries. ${ }^{11}$

This information is consistent with what has been reported by the qualitative research participants.

It appears that Bolivia was relatively better prepared to face the crisis. The country had a stronger economy due to revenues from the extractive industries sector and a government committed to inclusive social development. In response to the crisis, measures were implemented for regulating price levels and for facilitating the population's access to food. While some of these measures have been criticised for not working optimally, they did reach part of the neediest population, as some participants in the qualitative research could report. Since the crisis, the government has continued to implement cash transfer programmes to support poor and vulnerable people and maintained price ceilings and price monitoring on key products for the Bolivian diet.

Guatemala was less well prepared. While there were poverty reduction measures in place at the time of the crisis, there was no clear response from the government to develop or modify these measures in order to respond to the food price crisis. A new 


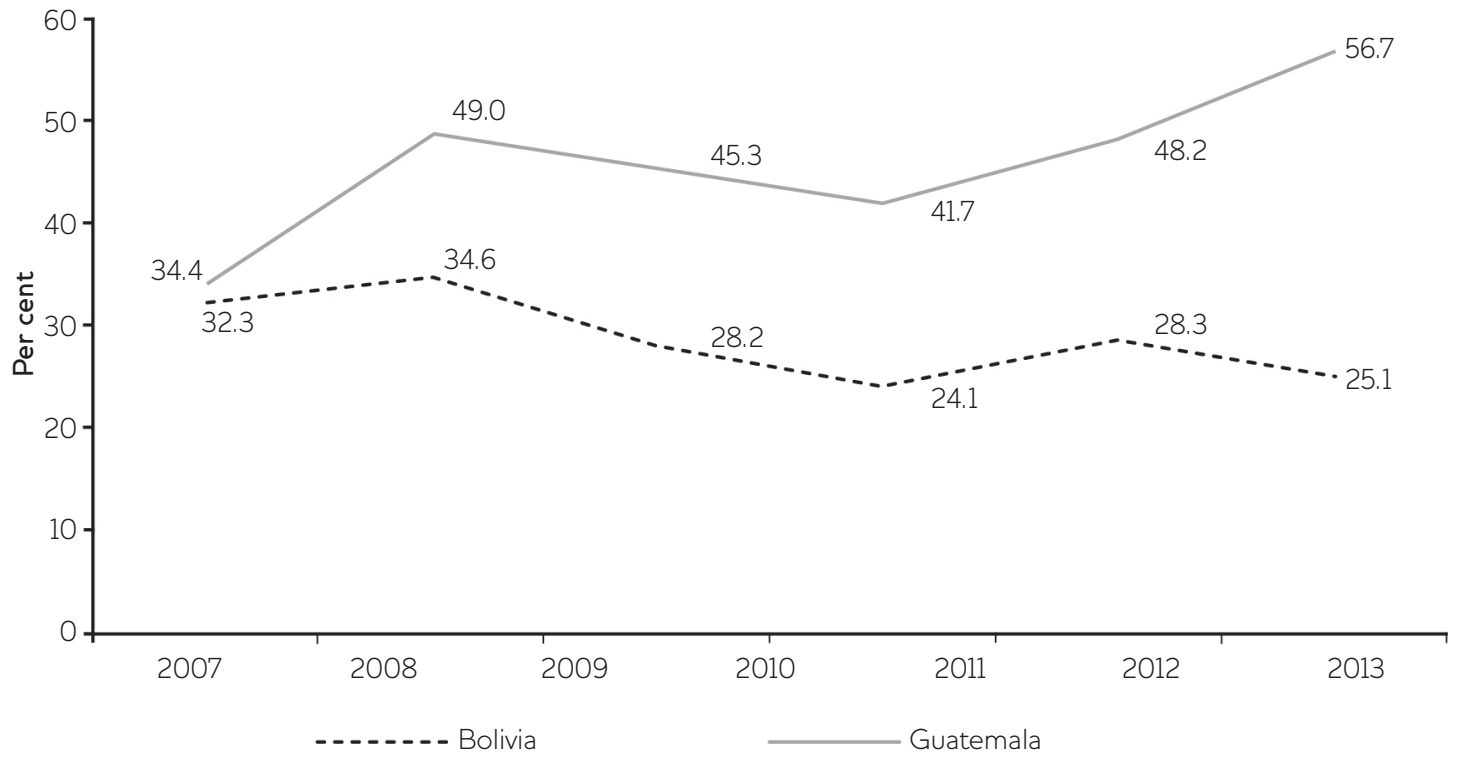

Source Latinobarómetro (n.d.) data 2007-13.12

president took office in 2008, at a moment when the crisis was ongoing. With a new administration getting established and a myriad of issues to be tackled at the country level, the response to the crisis was deficient. Furthermore, since then, there has been little oversight of food price movement and action to protect consumers, particularly the poorest.

\section{Household experience and responses to food price changes}

In 2008, a broad majority of respondents in the Latinobarómetro opinion survey indicated being very concerned that rising food prices would affect the family economy (over 66 per cent in Bolivia and 81 per cent in Guatemala). By 2009, the same survey showed that moderate to severe crisis impacts in the economy, both at the national and personal level, were being felt by a large proportion of the population in both countries. Economic concerns added weight to other issues already afflicting the population, such as unemployment, political instability, poverty; and insecurity and violence (particularly relevant for Guatemalans). This sense of hardship was clearly articulated by Mrs C., a 66-year-old small shop owner in Kami in 2012:

What concerns me the most is the situation of the country; money is never enough, there are strikes, roadblocks, food is scarce... there is homelessness. I rent and moving from one house to another is hard. I am also concerned because there is a gas shortage. How can I cook? How can I feed my children and grandchildren?
While the poorer households still report many difficulties to date for achieving a satisfying standard of living, the Latinobarómetro data show that the population in both countries faced greater difficulties for purchasing food between 2007 and 2008 than in 2009 and 2010. The reoccurrence of food price increases since 2011, as documented in several sources and reported by the qualitative research participants has led to further deterioration in the situation, particularly in the case of Guatemala where the proportion of persons with insufficient money to buy food continues to rise. While data for 2006 are not available, it is possible that a lower proportion of persons had difficulties buying food than in the 2007-08 and post-2010 period.

For both countries people have been experiencing a constant rise in food prices, rather than price volatility. While seasonal price variations are known and recognised, the general agreement of the qualitative research participants is that prices have mainly increased over time.

In response to this challenging economic situation, qualitative research participants indicated as early as 2012 that household incomes were being increasingly generated through engagement in multiple occupations and increased participation of children in the labour market. This frequently occurred at the expense of education.

For both countries, the living conditions survey data does not reflect the increase in multiple occupations 
between 2006 and 2011 at the national level. The contradiction of these data and the information gathered in the qualitative research sites might suggest that engagement in multiple occupations is common only in communities with certain social and economic characteristics and a high degree of poverty. Hence, group specificities will not necessarily hold for the larger population.

With respect to child labour, contrary to what was reported in the qualitative research in Guatemala, the proportion of children engaged in an economic activity at the national level decreased between 2006 and 2011 , from 25 to 20 per cent. ${ }^{13}$ This decrease was accompanied by an increase in exclusive school attendance. The achievement was attributed to expansion of income support and education programmes targeted to the poorer population segments in the country. The increase in multiple occupations and child labour reported in the studied communities is most likely to be related to their underlying high poverty rate and the decreased economic activity in these sites in particular. The rural study community depends to a considerable extent on revenues from tourism and textiles, for example, both sectors hard hit during the crisis.

Between 2006 and 2011 the proportion of children at work in Bolivia did not change much (both years around 29 per cent) according to survey estimates. However, the proportion of children who work and attend school reduced significantly in 2011 when compared to the 2006 level, especially in the rural areas. Thus, the survey data does not reflect an increase in child labour as reported in the qualitative results; however, it does confirm that more working children in the rural areas were forgoing education than was previously the case.

With respect to food consumption patterns, the qualitative research in both countries found that in the face of high/increasing food prices, households have changed the way they eat. On the one hand, more household resources are being spent on buying food, forgoing expenditure on other household needs. On the other hand, the foods purchased are either of lower quality than desired, or the quantities purchased are lower than in 'normal' situations. While some food products have been substituted by other cheaper products or by lower quality options, some foods have been given up altogether. This reality is captured by Mrs T., a 32-year-old rural housewife and laundrywoman from Guatemala who commented on her family's dietary practices in 2013: 'This year everything increased [in price]...
We buy the cheaper things... We buy smaller amounts and each of us eats a bit less... We can't buy all we need any more.' These results agree with what has been reported in the literature. According to Iannotti and Robles (2011), higher food prices can induce a dietary change on which (a) high quality and more expensive food items are substituted by cheaper or lower quality foods, and/or (b) the food quantities for the regularly consumed products are reduced given the lower purchasing power of the households.

In relation to the amount of food available to household members, the analysis of survey data in Bolivia showed that food availability ${ }^{14}$ was similar in 2006 and 2011 (around 2,050kcal per capita per day) at the aggregate national level. However, in 2011 food expenditures (per capita) were higher than in 2006. ${ }^{15}$ Hence, households were spending more for the same amount of food. As a participant in the qualitative research exemplified (Ms M., 18-yearold urban student and informal worker, 2012), the increase in food prices is strongly felt by those living in poverty in Bolivia: 'Food [prices] have risen. Now the money is not enough for buying them [different products]. Before, I use to spend 30 Bs per week.... now I have to spend 50 Bs.'

The situation in Guatemala was similar. According to Chaparro (2012), almost 62 per cent of all Guatemalan households reported in 2008-09 having reduced the consumption of certain food items. In a simulation of the 2007-08 food price shock, Iannotti et al. (2012) found that for most food groups, calorie and micronutrient intake diminished in the face of increasing prices and the reduction on real income. By 2011, 80 per cent of Guatemalan households were considered as food insecure after assessing their situation with the Latin American and Caribbean Food Security Scale - ELCSA (FAO 2012).

\section{The role of formal and informal social protection}

When facing a situation of crisis, people seek support from both formal (government, other institutions) and informal (relatives, acquaintances, money lenders) social protection mechanisms in order to secure a minimum standard of living. In general terms, during the food price crisis Latin American governments supported the population through social policies focused on lessening the impact of the increased food prices on income and on protecting employment. Among the instruments used to implement such policies were cash transfers, subsidies, price control and food distribution programmes. Some countries implemented wage increases, trainings, 
unemployment insurance, youth employment programmes and reductions in working hours and in contributions to social security (CEPAL 2012).

For both countries, the qualitative research has shown that access to formal social protection systems is low and there is a feeling of being left to cope alone. Bureaucracy, local political dynamics and lack of information on support options and the procedures to access them, limit people's chances of getting access to government support. Householders explained that organisations such as churches and non-governmental organisations (NGOs) are the main support providers at the local level in both countries. While the quantitative research could not verify the access and constraints to government support, the Latinobarómetro data does reflect that people have more trust in religious institutions/churches than in the government. In the $2006-10$ period, up to 80 per cent of the survey respondents in both countries reported trusting religious institutions/churches. The level of trust in the government was around 50 per cent in Bolivia and 30 per cent in Guatemala, over the same 2006-10 period.

Neither are the prospects encouraging with respect to informal social support. For instance, in Bolivia, research has found that social cohesion and cooperative behaviour declined in the 2006-09 period (Hernani-Limarino and Villegas 2010). The qualitative research participants mentioned that the traditional custom of helping each other is no longer practised and that there is a lack of engagement in community initiatives. Thus, with little access to formal social protection and to help from others in their communities or circle of acquaintances, a large proportion of Bolivian households have no other option than to face crises and shocks on their own. The Latinobarómetro data from 2009 showed that 63 per cent of the population was not confident that the government could protect them from a prolonged economic crisis.

In Guatemala the situation is similar. Formal social protection is available only to some and accessing it is not always easy or transparent. Furthermore, social cohesion and trust was severely damaged over the decades of conflict, which resulted in weakened social ties and lowered trust in government. ${ }^{16}$ In line with the qualitative research, González Tablada (2005) found that recreational groups, religious groups and rehabilitation groups (alcohol, drugs) are the formal organisations or institutions in which people in Guatemala have the greatest trust. It is family and the networks that grow from these groups that support people in their times of need.

\section{Conclusions}

For Bolivia and Guatemala, the mixed-method research project has shown over the course of three years that increasing food prices have impacted individual and family wellbeing, particularly for those living in poverty and this in turn has led to aggregate changes at the level of the population and the economy. It demonstrates the strength of the research approach in connecting macro-change, with micro-response, which in turn leads to macrooutcomes (see Hossain, this IDS Bulletin).

Households have coped and adapted to their current economic stress through a diverse set of mechanisms that have affected not only immediate family structures, dynamics and productivity, but also their future economic prospects, since both human and economic assets are used to address current needs. At an aggregate level the outcomes are substantial. The reported and measured changes in dietary quality and intake have certainly had an impact on the population's nutritional status and general health. Some of the effects are already visible locally, where malnutrition has increased and people talk about low school performance, tiredness and lack of energy for physical work. Other aggregate effects include adjustment in patterns of labour and a fundamental change in social relations, as tendencies for mutual support reduce with increasing commodification of the economy. Longer-term effects at the national level will likely follow in the coming years.

With sustained high and increasing prices, as reported in the research communities, both countries need to establish permanent measures to ensure the population's access to affordable and nutritious foods. While different government efforts were made in order to protect the neediest in both countries as a response to the 2007-08 crisis, there is still a long way to go to (1) facilitate the access to quality employment and the observance of minimum wages; (2) ensure that social protection reaches its target population in an adequate and timely manner; and (3) strengthen social cohesion and the sense of solidarity in the population. Longerterm solutions to rising food prices and economic hardship are needed in both countries. 


\section{Notes}

1 The two qualitative research sites are Pirhuas and Kami. Pirhuas in Sipe Sipe municipality, Cochabamba Province, is a rural community traditionally engaged in agriculture. Some of the qualitative research participants are related to the dairy industry (milk production) or to the extraction of aggregates (stone collection). It is an 'average' community in the Cochabamba Valley. In the past, many of the local inhabitants migrated abroad or to other regions in the country. During the past 15 years, some of these migrants have returned and/or are currently investing in their community and others sold their land to private enterprises. These new investments triggered infrastructure development (road, public lighting and transportation) and community growth. The adult population is the majority in the community.

The Kami neighbourhood in Quillacollo is close to a major highway connecting Cochabamba with La Paz and an industrial area. It owes its name to the Kami mine, located nearby and which in former times employed a significant proportion of the population. It is an old neighbourhood which once attracted rural migrants and it is representative of poor urban neighbourhoods in the Cochabamba area. Kami is densely populated and is home to a large proportion of retired miners and their families. In former times, emigration from Kami to other cities or countries was frequent. While mining is less relevant for the area in present times, the mining past of the region can be seen by the presence of mining associations and mining groups. These associations still play an important role in the community. Many of the persons participating in the qualitative research have a mining background (either directly or as a family member). The infrastructure in the community has improved in the past years. Public and private schools are available for the younger generations.

In Guatemala, the participating communities are Chugüexa Primero (rural) and Santo Tomás Chichicastenango (urban). Both are located in El Quiché Province (departamento) in western Guatemala, where poverty and food insecurity is widespread. About 98 per cent of the population in the area is of Mayan K'ich'e descent. The urban community, Santo Tomás Chichicastenango, attracts national and international tourism due to its local culture and traditional markets. Traditional customs of representation and authority is still exercised in the town. Thursdays and Sundays are especially important days during the week, since most commercial transactions take place in the markets set up these days. It is common to see people coming from nearby communities to trade goods (including textiles and handicrafts) in the markets. The rising levels of violence and insecurity in the country have negatively impacted the flow of tourists to Chichicastenango, affecting the livelihoods and income prospects of a large share of the local population. Chugüexa Primero is a rural indigenous community where the local language and customs remain in place. The population is also engaged in commerce, tailoring and textile production. Once key as community livelihood options, these activities have been seriously undermined by the internal conflict and the increasing competition from clothing (new and used) imported cheaply from the US. Some agriculture takes place in the area; however, due to land fragmentation, low productivity and engagement in other economic activities, it is not the main income source for the community.

2 Full qualitative and quantitative research reports are available from the project page: http://policy-practice.oxfam.org. uk/our-work/food-livelihoods/food-pricevolatility-research\#f4805efd-e266-4241-901ff8d88103bcfe.

3 From here onwards and for the purpose of simplification, only 'Bolivia' will be used when referring to the Plurinational State of Bolivia.

4 Author's own calculations based on the Living Conditions Household Survey data.

5 In 2009, Guatemala experienced a severe drought which affected thousands of families. Hurricane Agatha (2010), tropical depression 12-E (2011) and the widespread coffee rust (2013) have further compromised the livelihoods of hundreds of thousands of people.

6 Weather: www.eldiario.net/noticias/2014/2014_05/ nt140516/economia.php?n=10\&-buscan-garantizarprovision-de-productos-de-canasta-familiar; www.la-razon.com/economia/BCB-nivelinflacion-efecto-sequia_0_1219678061.html; www.la-razon.com/sociedad/reses-mueren-frioCotoca_0_1216678341.html.

7 Agricultural inputs: www.la-razon.com/ economia/Avicolas-emergencia-precio-comienzaelevarse_0_1244875556.html.

8 Wage increases and remittances: www.eldiario. net/noticias/2014/2014_06/nt140608/ economia.php?n=26\&-sube-precio-de-alimentosen-canasta-familiar. 
9 For instance, protests and tensions have risen due to the increase in fuel prices, the low level of old age pensions and support to the disabled, detention of soldiers, government decisions on how to use hydrocarbon revenues, infrastructure development in the TIPNIS area, and so forth.

10 Blockades: www.la-razon.com/nacional/genteacudio-masa-mercados-bancos_0_1228677134. html.

11 The following press articles document increases in food prices in different locations within Bolivia, at different points in time: www.eldiario.net/noticias/2014/2014_08/ nt140807/economia.php?n=22\&-pronosticanbaja-de-precios-de-alimentos; www.eldiario. net/noticias/2014/2014_06/nt140630/ nacional.php?n=41\&-se-espera-que-preciode-carne-baje-a-partir-de-hoy; www.eldiario. net/noticias/2014/2014_06/nt140608/ economia.php?n=26\&-sube-precio-dealimentos-en-canasta-familiar; www.eldiario.net/ noticias/2014/2014_05/nt140505/economia.

\section{References}

CEPAL (2012) Estudio Económico de América Latina y el Caribe. Las Políticas ante las Adversidades de la Economía Internacional, Santiago: CEPAL

Chaparro, Camila (2012) Inseguridad Alimentaria en el Hogar y Situación Nutricional de las Mujeres en Edad Reproductiva y de los Niños Menores de 5 Años en Cinco Departamentos del Altiplano Occidental de Guatemala: Análisis de los Datos de la Encuesta Nacional de Salud Materno Infantil del 2008-2009 en Guatemala, Washington DC: FHI 360/ FANTA

ECLAC (2013) 'Plurinational State of Bolivia', Preliminary Overview of the Economies of Latin America and the Caribbean 2012, Santiago, http://repositorio.cepal.org/bitstream/ handle $/ 1$ 1362/987 /Bolivia_en.pdf? sequence $=47$ (accessed 6 September 2015)

ECLAC (2010) Economic Survey of Latin America and the Caribbean 2009-10. The Distributive Impact of Public Policies, Santiago: ECLAC

FAO (2012) Escala Latinoamericana y Caribeña de Seguridad Alimentaria (ELCSA): Manual de Uso y Aplicaciones, Comité Científico de la ELCSA, Rome: FAO

Fundación Milenio (2014) Informe Milenio Sobre la Economía, Gestión 2013, Abril 2014, No. 36, La Paz: Fundación Milenio

González Tablada, C. (2005) 'El Capital Social y la Pobreza en Guatemala', Revista ASIES 1: 47

Hernani-Limarino, W.L. and Villegas, M.A. (2010) 'Understanding Changes in Social Cohesion in Bolivia', paper prepared for the php?n=59\&-precios-de-alimentos-se-mantienenestables-en-centros-de-abasto; www.la-razon. com/economia/productos-subieron-preciomercados_0_1260473969.html; www.la-razon. com/economia/Avicolas-emergencia-preciocomienza-elevarse_0_1244875556.html; see Chaparro (2012) for the case of Guatemala.

12 In 2006, this data wasn't collected; therefore, we cannot compare it with the base/reference year.

13 Results based on author's own calculations using the Living Conditions Household Survey data.

14 The calculations only included food items purchased or produced by the household and consumed within the household.

152006 figures have been adjusted to 2011 terms using the corresponding Consumer Price Index.

16 This result is further exemplified through the Latinobarómetro data, which in 2009 shows that about 75 per cent of the Guatemalan population was not confident that the government could protect them from a prolonged economic crisis.

International Conference of Social Cohesion and Development, OECD, Paris, 20-21 January 2011 Iannotti, L. and Robles, M. (2011) 'Negative Impact on Calorie Intake Associated with the 2006-08 Food Price Crisis in Latin America', Food and Nutrition Bulletin 32.2: 112-23

Iannotti, L.L.; Robles, M.; Pachón, H. and Chiarella, C. (2012) 'Food Prices and Poverty Negatively Affect Micronutrient Intakes in Guatemala', Journal of Nutrition 142. 8: 1568-76 IMF (2014) Bolivia. Staff Report for the 2013 Article IV Consultation, Country Report 14/36, Washington DC: International Monetary Fund

INE (201 la) Encuesta de Hogares 2011, Instituto Nacional de Estadística (INE) de Bolivia, www.ine.gob.bo:8081/Webine10/enchogares1.aspx (accessed 3 September 2015)

INE (201 1b) Encuesta Nacional de Condiciones de Vida 2011, Instituto Nacional de Estadística (INE) de Guatemala, http://ine.gob.gt/index.php/ encuestas-de-hogares-y-personas/condiciones-devida (accessed 2 September 2015)

INE (2006a) Encuesta de Hogares 2006, Instituto Nacional de Estadística (INE) de Bolivia, www.ine.gob.bo:8081/Webine10/enchogares 1.aspx (accessed 3 September 2015)

INE (2006b) Encuesta Nacional de Condiciones de Vida 2006, Instituto Nacional de Estadística (INE) de Guatemala, http://ine.gob.gt/index.php/ encuestas-de-hogares-y-personas/condiciones-devida (accessed 2 September 2015) 
KAS and laRED (2010) Crisis Financiera Mundial: Su Impacto Económico y Social en Centroamérica, Guatemala City: Konrad Adenauer Stiftung, Red Centroamericana de Centros de Pensamiento e Incidencia

Latinobarómetro (n.d.) Opinion Survey Data 20062013, www.latinobarometro.org/lat.jsp (accessed 3 September 2015)
PMA (2008) Alza de Precious, Mercados e Inseguridad Alimentaria y Nutricional el Centroamérica: Capitulo Guatemala, Guatemala City: PMA

World Bank (2014) Guatemala Economic DNA:

Harnessing Growth with a Special Focus on Fobs, First Edition, August, Guatemala City: World Bank Group 